\title{
Minat Penggunaan Produk dan Layanan Pegadaian Syariah: Studi Kasus Nasabah di Sidrap Sulawesi Selatan
}

\author{
Sulkarnain \\ IAIN Parepare \\ Email: sulkarnain@iainpare.ac.id
}

\begin{abstract}
This research aims at disclosing the motivations of customers to use product and service in Pegadaian Syariah. The type of this research is quantitative. The object of this research was in Pegadaian Syariah Sidrap of Sulawesi Selatan. The respondents were 95 customers. The technique of data analysis used statistics descriptive. The result found that the respondents are higher to use sharia product and service in Pegadaian Syariah due to self-need and pressure.
\end{abstract}

Keywords: Customer, Interest, Pawn.

Abstrak. Penelitian ini bertujuan untuk mengungkapkan motivasi para nasabah menggunakan produk dan layanan di Pegadaian Syariah. Jenis penelitian ini adalah kuantitatif. Lokasi penelitian dilakukan pada Pegadaian Syariah Sidrap Sulawesi Selatan. Responden dalam penelitian ini sebanyak 95 Nasabah. Teknis analisis data menggunakan statistik deskriptif. Hasil penelitian ini mengungkapkan bahwa responden lebih banyak memilih penggunaan produk dan layanan di Pegadaian Syariah karena keinginan sendiri dan kebutuhan mendesak.

Kata Kunci: Nasabah, Minat, Pegadaian.

\section{PENDAHULUAN}

Pegadaian merupakan salah satu alternatif pendanaan yang sangat efektif karna tidak memerlukan persyaratan rumit yang dapat menyulitkan nasabah dalam pemberian dana. Cukup dengan membawa KTP, Kartu Keluarga barang jaminan yang bernilai ekonomis, masyarakat sudah mendapatkan dana untuk kebutuhannya. Di samping itu proses pencairan dana yang terbilang cepat dan mudah. Pada masa krisis Perum Pegadaian mendapat peluang untuk semakin berperan dalam pembiayaan, khususnya untuk usaha kecil, dan ternyata selama kurun waktu krisis ekonomi nasional tersebut, Perum Pegadaian dapat menunjukkan kinerja yang memuaskan dan menjadi salah satu perusahaan yang tidak begitu berpegaruh oleh krisis (Hermawan, 2001).

Namun hal itu tidak perlu di khawatirkan lagi, karena sekarang ini selain terdapat pegadaiaan konvensional, beroperasi pula pegadaian syariah yang memang didirikan oleh Perum Pegadaian Syariah yang memang didirikan oleh Perum Pegadaian. Pengembangan konsep syariah ini merupakan upaya pegadaian untuk menghindari riba.

Pegadaian syariah tidak menekankan pada pemberian bunga dari barang yang digadaikan. Meski tanpa bunga, pegadaian syariah tetap memperoleh keuntungan seperti yang diatur oleh Dewan Syariah Nasional, yang memberlakukan biaya pemeliharaan dari barang yang digadaikan. Biaya itu dihitung dari nilai barang, bukan jumlah pinjaman. Pada umumnya masyarakat tidak memahami pemasaran, mereka melihat pemasaran sebagai sebuah penjualan. Padahal pemasaran ini mempunyai arti lebih luas karena pemasaran adalah suatu proses yang teratur dan jelas untuk memikirkan dan merencanakan pasar. Proses pemasaran dapat diterapkan tidak sekedar pada batang dan jasa, tetapi juga pada segala sesuatu yang dapat dipasarkan sepeti ide, kejadian, organisasi, tempat, kepribadian. Namun penting untuk ditekankan bentuk pemasaran tidak dimualai dengan suatu produk penawaran, tetapi dengan pencarian peluang pasar (Hendra dkk., 1997). Dalam perspektif ekonomi, pegadaian merupakan salah satu alternatif pendanaan yang sangat efektif karena 
tidak memerlukan proses dan persyaratan yang rumit. Pegadaian melaksanakan kegiatan lembaga keuangan berupa pembiayaan dalam bentuk penyaluran dana ke masyarakat atas dasar hukum gadai. Tugas pokok dari lembaga ini adalah memberikan pinjaman kepada masyarakat yang membutuhkan. Lembaga Keuangan Gadai Syariah mempunyai fungsi sosial yang sangat besar. Karena pada umumnya, orang -orang yang datang ke tempat ini adalah mereka yang secara ekonomi sangat kekurangan dan biasanya pinjaman yang dibutuhkan adalah pinjaman yang bersifat konsumtif dan sifatnya mendesak.

Dalam implementasinya, pegadaian syariah merupakan kombinasi komersilproduktif, meskipun jika kita mengkaji latar belakang gadai syariah, baik secara implisit maupun eksplisit lebih berpihak dan bertujuan untuk kepentingan sosial. Sebagai lembaga keuangan syariah non-bank milik pemerintah bertujuan untuk menyediakan tempat badan usaha bagi orang-orang yang menginginkan prinsip-prinsip syariah bagi masyarakat muslim (Abbas, 2019) khususnya dan pada semua lapisan masyarakat non-muslim pada umumnya. Di samping itu untuk memenuhi kebutuhan umat akan jasa gadai yang sesuai syariah. Sifat usaha pegadaian pada prinsipnya menyediakan pelayanan bagi kemanfaatan masyarakat umum dan sekaligus memupuk keuntungan berdasarkan prinsip pengelolaan yang baik. Oleh karena itu Pegadaian Syariah pada dasarnya mempunyai tujuan-tujuan pokok seperti dicantumkan dalam PP No. 103 tahun 2000 sebagai berikut:

1. Turut melaksanakan dan menunjang pelaksanaan kebijaksanaan dan program pemerintah di bidang ekonomi dan pembangunan nasional pada umumnya melalui penyaluran uang pembiayaan/pinjaman atas dasar hokum gadai

2. Pencegahan praktik ijon, pegadaian gelap, dan pinjaman tidak wajar lainnya

3. Pemanfaatan gadai bebas bunga pada gadai syariah memiliki efek jarring pengaman social karena masyarakat yang butuh dana mendesak tidak lagi dijerat pinjaman/pembiayaan berbasis bunga

4. Membantu orang-orang yang membutuhkan pinjaman dengan syarat mudah.
Banyak manfaat lain yang bisa diperoleh dari pegadaian syariah. Pertama, prosesnya cepat. Dalam pegadaian syariah, nasabah dapat memperoleh pinjaman yang diperlukan dalam waktu yang relatif cepat, baik proses administrasi, maupun penaksiran barang gadai. Dua cara tersebut cukup mudah. Yakni hanya dengan membawa barang gadai beserta bukti kepemilikan. Ketiga, jaminan keamanan atas barang diserahkan dengan standar keamanan yang telah diuji dan diasuransikan dan sebagainya. Adapun manfaat pegadaian antara lain (Ghofur, 2005), bagi nasabah, tersedianya dana dengan prosedur yang relative lebih sederhana dan dalam waktu yang lebih cepat dibandingkan dengan pembiayaan/kredit perbankan. Di samping itu, nasabah juga mendapat manfaat penaksiran nilai suatu barang bergerak secara professional. Mendapatkan fasilitas penitipan barang bergerak yang aman dan dapat dipercaya.

Minat adalah suatu rasa dan suatu ketertarikan pada suatu hal aktivitas tanpa ada yang menyuruh dan timbul tidak secara tiba-tiba atau spontan,melainkan timbul akibat partisispasi, pengetahuan dan kebiasaan. Minat juga diartikan sebagai kondisi yang terjadi disertai perasaan senang dihubungkan dengan kebutuhan atau keinginannya sendiri. (Amir, 2008). Minat sebagai aspek kejiwaan bukan hanya mewarnai perilaku seseorang merasa tertarik kepada sesuatu. Sedangkan nasabah merupakan konsumen-konsumen sebagai penyedia dana dalam proses transaksi barang ataupun jasa. Secara etimologi minat adalah perhatian kesukaan (kecenderungan hati) kepada suatu keinginan (Poerdawarminta, 2008). Adapun pengertian minat secara terminologi, terdapat beberapa pengertian minat yang ditemukan oleh para ahli, diantaranya yaitu menurut Syah (2000) minat yang berarti kecenderungan dan kegairahan yang tinggi atau keinginan yang besar terhadap sesuatu.

Berdasarkan hal tersebut yang membuat penulis tertarik untuk meneliti mengenai motivasi nasabah menjadi pengguna produk dan layanan pegadaian syariah dengan melihat minat nasabah di pegadaian syariah sidrap. 


\section{METODE}

Jenis penelitian ini adalah penelitian deskriptif kuantitatif. Sugiyono (2003) menyatakan bahwa penelitian deskriptif adalah penelitian yang dilakukan untuk mengetahui nilai variable mandiri, baik satu variable atau lebih tanpa membuat perbandingan, atau menghubungkan dengan variable yang lain. Sedangkan deskriptif kuantitatif adalah data yang diperoleh dari sampel populasi penelitian dianalisis sesuai dengan metode statistik yang digunakan kemudian diinterpretasikan.

Lokasi penelitian yang akan dijadikan sebagai tempat pelaksanaan penelitian yang berkaitan dengan masalah yang diangkat dalam penelitian ini adalah Pegadaian Syariah Sidrap yang bertempat di Jl. Jend Ahmad Yani No. 111 Kelurahan Lautang Benteng. Kecamatan Maritengngae. Kabupaten Sidenreng Rappang. Populasi adalah keseluruhan jumlah yang terdiri atas obyek atau subyek yang mempunyai karakteristik dan kualitas tertentu yang ditetapkan oleh peneliti untuk diteliti dan kemudian ditarik kesimpulannya (Sugiyono, 2014). Populasi dalam Penelitian Ini adalah nasabah pembiayaan di cabang Pegadaian syariah Kab. Sidrap.

$$
\text { Jumlah }
$$

Maritengngae.

populasi

Kabupaten

Kecamatan

Rappang.tersebut yang paling sedikit dari 12 Desa/Kelurahan di Kec Marritenggae. Populasi penduduk pada tahun 2016 meningkat tajam seiring bertambahnya penduduk, lapangan kerja juga diperlukan (Abbas, 2019)

Sampel adalah bagian dari jumlah dan karakteristik yang dimiliki oleh populasi tersebut. Adapun sampel yang gunakan adalah jumlah keseluruhan dari populasi. Teknik Sampling adalah merupakan Teknik Pengambilan Sampel. Untuk menentukan sampel yang akan digunakan dalam penelitian, terdapat berbagai Teknik Sampling yang di gunakan (Nasution, 2002).

Teknik pengambilan sampel pada penelitian ini adalah sampling jenuh. sampling Jenuh adalah teknik penentuan sampel bila semua anggota populasi digunakan sebagai sampel. Hal ini sering dilakukan bila jumlah populasi relatif kecil. Dalam penelitian ini yang menjadi sampel adalah sebagian nasabah dari tahun 2016 - 2018.

Rumus:

$\mathrm{n}=$ Ukuran sampel

$$
\mathrm{n}=\frac{\mathrm{N}}{1+\mathrm{Ne}^{2}}
$$

$\mathrm{N}=$ Populasi

$\mathrm{e}=\%$ kelonggaran ketidaktelitian karena kesalahan $(10 \%)$

Besarnya populasi diketahui sebesar 2.000 orang. Jadi besarnya sampel yang digunakan adalah:

$$
\begin{gathered}
n=\frac{2.000}{1+2.000(0.01)^{2}} \\
n=\frac{2.000}{21} \\
\quad=95
\end{gathered}
$$

Metode pengumpulan data yang tepat memungkinkan diperolehnya data yang objektif pada penelitian ini adalah kuesioner. Kuesioner yaitu teknik pengumpulan data yang dilakukan dengan cara memberikan seperangkat pertanyaan atau pernyataan tertulis kepada responden untuk dijawabnya. Jawaban setiap instrumen menggunakan skala likert. Skala Likert digunakan untuk mengukur sikap, pendapat, dan persepsi seseorang atau sekelompok orang tentang fenomena sosial. Metode selanjutnya adalah dokumentasi.

Teknis analisis data dalam penelitian ini menggunakan statistik deskriptif. Menentukan level minat berdasarkan skala likert kemudian menemukan total nilainya.

\section{HASIL DAN PEMBAHASAN}

Dari Tabel 1, diketahui bahwa responden yang berjumlah 95 orang dimana Laki-laki berjumlah 25 atau $26,3 \%$ sedangkan perempuan berjumlah 70 atau $73,7 \%$ dan dapat disimpulkan bahwa responden terbanyak adalah nasabah perempuan yaitu sebanyak 70 responden atau sebesar 73,7\%.

Tabel 1. Karakteristik Berdasarkan Jenis Kelamin

\begin{tabular}{|l|l|c|}
\hline Jenis kelamin & Jumlah & $\%$ \\
\hline Laki-Laki & 25 & $26,3 \%$ \\
\hline Perempuan & 70 & $73,7 \%$ \\
\hline
\end{tabular}

Sumber: Data diolah dari kuesioner 2019 
Adapun item-item dalam variabel Minat nasabah pada kuesioner atau angket peneliti memasukkan 7 pertanyaan sebagai berikut.

1. Saya berminat menggunakan produk gadai karena kebutuhan yang mendesak

2. Karena fleksibel masyarakat jadi tertarik menjadi nasabah

3. Dengan adanya pegadaian syariah masyarakat dengan aman menggadaikan barang berharganya tanpa rasa khawatir

4. Saya tertarik pada pegadaian syariah karena tidak memiiki bunga melainkan biaya Ujrah

5. Saya berminat di pegadaian syariah karena menerapkan system syariah

6. Lokasi yang mudah ditemukan

7. Saya menjadi nasabah di pegadaian syariah karena keinginan diri sendiri.

Tabel 2. Item 1 Saya berminat menggunakan produk gadai karena kebutuhan yang mendesak

\begin{tabular}{l|l|l|}
\hline \multicolumn{1}{|c|}{ Skala } & Frequency & Percent \\
\hline Sangat Tidak Setuju & 0 & 0 \\
Tidak Setuju & 0 & 0 \\
Netral & 9 & 9.5 \\
Setuju & 63 & 66.3 \\
Sangat setuju & 23 & 24.2 \\
Total & 95 & 100.0 \\
\hline
\end{tabular}

Sumber. Data diolah, 2019

Berdasarkan Tabel 2, terlihat 9 responden atau 9,5\% menjawab netral, 63 responden atau $66,3 \%$ menjawab setuju, 23 responden atau $24,2 \%$ menjawab sangat setuju, dan tidak ada responden menjawab tidak setuju dan sangat tidak setuju. Dari pernyataan ini menunjukkan bahwa responden tertarik menggunakan produk gadai karena kebutuhan yang mendesak. Terlihat dari jumlah responden yang sebagian besar menjawab setuju yaitu berjumlah 63 responden atau $66,3 \%$ dan yang menjawab sangat setuju berjumlah 23 responden atau $24,2 \%$.
Tabel 3. Item 2

Karena fleksibel masyarakat jadi tertarik menjadi nasabah

\begin{tabular}{l|r|r|}
\hline Skala & Frequency & Percent \\
\hline Sangat Tidak Setuju & 0 & 0 \\
Tidak Setuju & 0 & 0 \\
Netral & 7 & 7.4 \\
Setuju & 58 & 61.1 \\
Sangat setuju & 30 & 31.6 \\
Total & 95 & 100.0 \\
\hline
\end{tabular}

Sumber: Data diolah, 2019

Berdasarkan Tabel 3, terlihat 7 responden atau $7,4 \%$ menjawab netral, 58 responden atau $61,1 \%$ menjawab setuju, 30 responden atau $31,6 \%$ menjawab sangat setuju, dan tidak ada responden menjawab tidak setuju dan sangat tidak setuju. Dari pernyataan ini menunjukkan bahwa responden tertarik menggunakan produk gadai karena produk ini fleksibel.

Terlihat dari jumlah responden yang sebagian besar menjawab setuju yaitu berjumlah 58 responden atau $61,1 \%$ dan yang menjawab sangat setuju berjumlah 30 responden atau $31,6 \%$.

Tabel 4. Item 3 Dengan adanya pegadaian syariah masyarakat dengan aman menggadaikan barang berharganya tanpa rasa khawatir

\begin{tabular}{l|r|r|}
\hline Skala & Frequency & Percent \\
\hline Sangat Tidak Setuju & 0 & 0 \\
Tidak Setuju & 0 & 0 \\
Netral & 6 & 6.3 \\
Setuju & 31 & 32,6 \\
Sangat setuju & 58 & 61,1 \\
Total & 95 & 100.0 \\
\hline
\end{tabular}

Sumber. Data diolah, 2019

Berdasarkan Tabel 5, terlihat 6 responden atau $6,3 \%$ menjawab netral, 31 responden atau $32,6 \%$ menjawab setuju, 58 responden atau $61,1 \%$ menjawab sangat setuju, dan tidak ada responden menjawab tidak setuju dan sangat tidak setuju.

Dari pernyataan ini menunjukkan bahwa responden tertarik menggunakan produk gadai karena adanya pegadaian syariah masyarakat 
dengan aman menggadaikan barang berharganya tanpa rasa khawatir. Terlihat dari jumlah responden yang sebagian besar menjawab setuju yaitu berjumlah sangat setuju berjumlah 58 responden atau $61,1 \%$.

Tabel 5. Item 4 Saya tertarik pada pegadaian syariah karena tidak memiiki bunga melainkan biaya Ujrah

\begin{tabular}{l|r|r|}
\hline Skala & Frequency & Percent \\
\hline Sangat Tidak Setuju & 0 & 0 \\
Tidak Setuju & 0 & 0 \\
Netral & 6 & 6.3 \\
Setuju & 31 & 32,6 \\
Sangat setuju & 58 & 61,1 \\
Total & 95 & 100.0 \\
\hline
\end{tabular}

Sumber. Data diolah, 2019

Berdasarkan Tabel 5, terlihat 6 responden atau $6,3 \%$ menjawab netral, 31 responden atau $32,6 \%$ menjawab setuju, 58 responden atau $61,1 \%$ menjawab sangat setuju, dan tidak ada responden menjawab tidak setuju dan sangat tidak setuju. Dari pernyataan ini menunjukkan bahwa responden tertarik menggunakan produk gadai karena adanya pegadaian syariah masyarakat dengan aman menggadaikan barang berharganya tanpa rasa khawatir. Terlihat dari jumlah responden yang sebagian besar menjawab setuju yaitu berjumlah sangat setuju berjumlah 58 responden atau $61,1 \%$.

Tabel 6. Item 5 Saya berminat di pegadaian syariah karena menerapkan system syariah

\begin{tabular}{l|l|l|}
\hline Skala & Frequency & Percent \\
\hline Sangat Tidak Setuju & 0 & 0 \\
Tidak Setuju & 0 & 0 \\
Netral & 12 & 12.6 \\
Setuju & 45 & 47.4 \\
Sangat setuju & 38 & 40.0 \\
Total & 95 & 100.0 \\
\hline
\end{tabular}

Sumber. Data diolah, 2019

Berdasarkan Tabel 6, terlihat 12 responden atau $12,6 \%$ menjawab netral, 45 responden atau $47,4 \%$ menjawab setuju, 38 responden atau $40.0 \%$ menjawab sangat setuju, dan tidak ada responden menjawab tidak setuju dan sangat tidak setuju. Dari pernyataan ini menunjukkan bahwa responden tertarik menggunakan produk gadai karena pegadaian syariah menerapkan system syariah. Terlihat dari jumlah responden yang sebagian besar menjawab setuju 45 responden atau 47,4\%, dan menjawab sangat setuju sebanyak 38 responden atau $40.0 \%$.

Tabel 7. Item 6

Lokasi yang mudah ditemukan

\begin{tabular}{l|r|r|}
\hline Skala & Frequency & Percent \\
\hline Sangat Tidak Setuju & 0 & 0 \\
Tidak Setuju & 0 & 0 \\
Netral & 33 & 34.7 \\
Setuju & 55 & 57.9 \\
Sangat setuju & 7 & 7.4 \\
Total & 95 & 100.0 \\
\hline
\end{tabular}

Sumber. Data diolah, 2019

Berdasarkan Tabel 7, terlihat 33 responden atau $34,7 \%$ menjawab netral, 55 responden atau 57,9\% menjawab setuju, 7 responden atau $7,4 \%$ menjawab sangat setuju, dan tidak ada responden menjawab tidak setuju dan sangat tidak setuju. Dari pernyataan ini menunjukkan bahwa responden tertarik menggunakan produk gadai karena lokasi yang mudah di jangkau. Terlihat dari jumlah responden yang sebagian besar menjawab netral sebanyak 33 responden atau 34,7\%.

Tabel 8. Item 7 Saya menjadi nasabah di pegadaian syariah karena keinginan diri sendiri

\begin{tabular}{l|r|r|}
\hline Skala & Frequency & Percent \\
\hline Sangat Tidak & 0 & 0 \\
Setuju & 0 & 0 \\
Tidak Setuju & 1 & 1,1 \\
Netral & 23 & 24.2 \\
Setuju & 71 & 74.7 \\
Sangat setuju & 95 & 100.0 \\
\hline
\end{tabular}

Sumber. Data diolah, 2019

Berdasarkan Tabel 8, terlihat 1 responden atau $1,1 \%$ menjawab netral, 23 responden atau 
$24,2 \%$ menjawab setuju, 71 responden atau $74,7 \%$ menjawab sangat setuju, dan tidak ada responden menjawab tidak setuju dan sangat tidak setuju. Dari pernyataan ini menunjukkan bahwa responden tertarik menggunakan produk gadai karena keinginan sendiri. Terlihat dari jumlah responden yang sebagian besar menjawab sangat setuju sebanyak 71 responden atau 74,7\%.

Adapun nilai total masing-masing item disajikan pada Tabel 9 sebagai berikut.

Tabel 9. Nilai Total Item

\begin{tabular}{|l|l|l|l|l|l|}
\hline & STS & TS & Netral & S & SS \\
\hline Item 1 & 0 & 0 & 9 & 63 & 23 \\
\hline Item 2 & 0 & 0 & 7 & 58 & 30 \\
\hline Item 3 & 0 & 0 & 6 & 51 & 38 \\
\hline Item 4 & 0 & 0 & 6 & 31 & 58 \\
\hline Item 5 & 0 & 0 & 12 & 45 & 38 \\
\hline Item 6 & 0 & 0 & 33 & 55 & 7 \\
\hline Item 7 & 0 & 0 & 1 & 23 & 71 \\
\hline Total & $\mathbf{0}$ & $\mathbf{0}$ & $\mathbf{7 4}$ & $\mathbf{3 2 6}$ & $\mathbf{2 6 5}$ \\
\hline
\end{tabular}

Responden yang menjawab SS atau Sangat Setuju memperoleh nilai total paling tinggi untuk semua item sebanyak 265 responden. Kemudian nilai total tertinggi selanjutnya adalah S (Setuju) sebanyak 326 responden dan terakhir Responden menjawab Netral sebanyak 74. Tidak ada jawaban STS (Sangat Tidak Setuju) serta TS (Tidak Setuju) yang diperoleh dalam kuesioner.

\section{KESIMPULAN}

Ada 7 item yang sudah dibangun dalam penelitian ini. Item 7 yang mengungkapkan "saya menjadi nasabah di pegadaian syariah karena keinginan diri sendiri" memperoleh nilai yang paling tinggi pada skala Sangat Setuju. Ini menandakan bahwa minat nasabah menggunakan produk dan layanan pegadaian syariah dimotivasi atas keinginan sendiri. Sebaliknya item 1 yang mengungkapkan bahwa "saya berminat menggunakan produk gadai karena kebutuhan yang mendesak" memperoleh nilai paling tinggi pada skala Setuju. Ini menunjukkan bahwa minat nasabah setuju menggunakan produk pegadaian syariah untuk kebutuhan mendesak. Pada skala netral, item 6 memperoleh nilai paling tinggi yang mengungkapkan bahwa "lokasi yang mudah ditemukan". Ini berarti para nasabah tidak mempersoalkan lokasi dalam melibatkan diri sebagai pengguna produk di pegadaian syariah.

\section{SARAN}

Adapun saran dalam penelitian ini adalah peneliti selanjutnya diharapkan dapat mengembangkan penelitian lanjutan dengan meneliti faktor-faktor lain yang diperkirakan dapat mempengaruhi minat nasabah seperti promosi sehingga dapat memberikan nilai yang lebih tinggi serta dapat menghasilkan wawasan yang lebih luas terhadap permasalahan yang diteliti. Bagi Pegadaian Syariah, sebaiknya meningkatkan pengetahuan kepada nasabah dengan melakukan sosialisasi atau promosi agar dapat meningkatkan pemakaian produk gadai dan jasa lainnya

\section{DAFTAR PUSTAKA}

Abbas, A. (2019). Analisis Laporan Keuangan Perbankan Syariah.

Abbas, A., Rayyani, W.O., \& Purnamasari, R. (2020). SHARIA BANKS AND THEIR BUSINESS EARNINGS: AN EMPIRICAL EXPLORATORY OF THE CASE OF INDONESIA. Airlangga International Journal of Islamic Economics and Finance, 3(1), 31-41.

Amir, Mahmud. (2008). Pengaruh Motivasi Terhadap Minat Mahasiswa Untuk Mengikuti Pendidikan Profesi Akuntan. Jurnal Pendidikan Ekonomi.

Ghofur, Abdul. (2005). Perbankan Syariah Indonesia. Yogyakarta: Gadjah Mada University Press.

Hendra, dkk. (1997). Manajemen Pemasaran: Analisis, Perencanaan, Implementasi dan Kontrol. Jakarta:PT. Prenhalindo

Hermawan. (2001). Syariah Marketing, Jakarta:Erlangga.

https://pegadaiansyariah.co.id/

https://pegadaiansyariah.co.id/gadai-syariah2410

Nanning, N., Abbas, A., \& Mujahidah, M. INCREASING THE ECONOMY OF VILLAGE COMMUNITY THROUGH BANANA WASTE MANAGEMENT. JCRS (Journal of Community Research and Service), 4(1), 1-8.

Nasution. (2002). Metode Penelitian Naturalistik Kualitatif. Bandung: Tarsito. 
Terakreditasi Peringkat 4 (No. SK: 36/E/KPT/2019)

Poerdawarminta, W.J.S. (2008.) Kamus Umum Bahasa Indonesia Edisi VI, cet. Ke-7. Jakarta: PT Balai Pustaka.

Sugiyono. (2003). Metode Penelitian Bisnis. Bandung: Pusat Bahasa Depdiknas.

Sugiyono. (2014). Metode Penelitian Bisnis. Bandung: Alfabeta.

Syah, Muhibbin. (2000). Psikologi Pendidikan. Bandung: PT Remaja Rosdakarya. 